\title{
The Antics of Semantics in International Law
}

\author{
Marika McAdam
}

\section{Response to the ATR Debate Proposition: 'It is important and necessary to make clear distinctions between (irregular) migrants, refugees and trafficked persons.'}

Please cite this article as: M McAdam, 'The Antics of Semantics in International Law', Anti-Trafficking Review, issue 11, 2018, pp. 125-128, www.antitraffickingreview.org

Whether a person is given a loaded label like 'irregular' migrant, refugee or trafficked person, can make the difference between arrest and protection, or between deportation and asylum, or between return to an uncertain fate and assistance for a decent life. In short, the distinctions we make in the language of international law may mean the difference between life and death.

But the categories we use are not mutually exclusive. Take for instance, a migrant who pays to be smuggled and is tortured to extort money from his parents before being delivered to his destination. He is not necessarily a victim of trafficking, but is a migrant who has experienced an aggravated form of smuggling and may have significant protection and assistance needs as a result. ${ }^{1}$ In contrast, at the point that a victim of trafficking is identified, he may not have suffered as much at the hands of his traffickers. The labels 'trafficked' or 'smuggled' then, may not speak to the specific plight or needs of the individuals they attach to. Similarly, the fact that a refugee falls victim to traffickers does not mean that she does not also have a well-founded fear of persecution, and the fact that a person pays to be smuggled does not mean that he is not a victim of trafficking or in search of asylum. Indeed, one situation may be a cause or result of another.

1 See article 6(3) of UN General Assembly, Protocol against the Smuggling of Migrants by Land, Sea and Air, Supplementing the United Nations Convention against Transnational Organized Crime, 15 November 2000.

This is an open-access article distributed under the terms of the Creative Commons Attribution License (CC-BY). Under the CC-BY license, the public is free to share, adapt, and make commercial use of the work. Users must always give proper attribution to the authors and the Anti-Trafficking Review. 
The value of these labels to those who ascribe them and those they are ascribed to comes from what is done with them. As it is, a smuggled migrant may be criminalised for that fact, contrary to international law, and be deported notwithstanding a valid claim not to be. A victim of trafficking may gain more from being considered an exploited migrant labourer, who can seek a civil remedy and receive the wages owed to her, than from being recognised as a victim and made to wait for months in a trafficking shelter for a criminal process which possibly does not result in any compensation. ${ }^{2}$ It might not matter to a refugee that she is not recognised as such under the 1951 Refugees Convention if she is spared from refoulement as a victim of trafficking or a survivor of torture.

Effort needs to be invested then not in forcing distinctions between terms, but in responsibly applying them so that people who fall-or rather, are placed-into these categories do not miss out on entitlements because of or despite the labels applied to them. Success in this endeavour does not lie in the extent to which tidy distinctions are cleaved between concepts, but in the extent to which the full raft of international treaties is leveraged for the benefit of those in need of assistance and protection.

Doing otherwise suggests that there may be disingenuous approaches taken to what should be good faith interpretations of international law. ${ }^{3}$ Those who would rather approach victims of trafficking as smuggled migrants may be seeking to take advantage of a lax understanding and application of the framework protecting smuggled migrants. And those who fixate, for instance, on disassociating 'refugees' from what it is to be a 'migrant' overlook the chaotic circumstances of individuals and the common shifts in factors driving human mobility. ${ }^{4}$ This 'one or the other' agenda fuels a destructive turf war over topic-territory that ultimately may come at the cost of meaningful

2 Based on the author's own consultations with practitioners. See also: A Testa and E Taylor-Nicholson, Enabling Access to Justice: A CSO perspective on the challenges of realising the rights of South Asian migrants in the Middle East, Global Alliance Against Traffic in Women, Bangkok, 2017, p. 25, retrieved 4 June 2018, http:/ /www.gaatw.org/resources/publications/919-enabling-access-to-justice-a-csoperspective-on-the-challenges-of-realising-the-rights-of-south-asian-migrants-inthe-middle-east.

3 Vienna Convention of the Law of Treaties 1969, Article 31.

4 See for instance: J Carling, 'Refugee Advocacy and the Meaning of "Migrants", PRIO Policy Brief 2, PRIO, Oslo, 2017. 
protection of the people caught in its crossfire. It also signals to those who work at the frontline and along the fault lines to respond to urgent human needs and who do not have the time, capacity or incentive to scrutinise and unravel the interconnected threads of international law, that 'migrant' is a label not worth having. To play tug-of-war over classifications is to treat as simple what is unquestionably complicated, and to surrender to political spin that would have us believe that 'irregular' migrants cannot also be victims of trafficking or that they have lesser rights to seek asylum than others.

When all is said and done though, there is one label that must be applied even when all others are tussled over, intellectualised, hierarchised and brutalised. Whether a refugee, trafficked person, smuggled migrant, 'irregular' migrant or formerly known as 'illegal' migrant, stateless, female, male, transgender, intersex, gay, straight or still experimenting and undecided-the category to which every person belongs, is this: human.

Human rights attach to us on the basis of our inherent dignity as human beings. These rights are not diminished when another label is ascribed to the human at issue, or by the circumstance she has placed herself in or has been placed in by others. Sometimes, in some contexts, clear distinctions can be made between migrants, refugees and trafficked persons. But when distinctions cannot be made on the basis of facts at hand, they should not be forced on the basis of the agendas at issue. In the current geopolitical climate, the architecture of international law is at risk of crumbling under the weight of disrespect and indifference, resulting in international organisations wielding semantics as a weapon in the fight for dwindling funds. The framework of human rights law is a casualty we cannot afford. Whatever labels may be ascribed to us, when it comes to human rights, it is important and necessary that we remain indistinguishable. ${ }^{5}$

5 Some of the ideas expressed in this article are more fully explored in: M McAdam, 'What's in a Name? Victim naming and blaming in rights-based distinctions between human trafficking and migrant smuggling', International Human Rights Law Review, vol. 4, issue 1, 2015, pp. 1-32. 
Marika McAdam is an independent legal consultant, scholar and adviser who has worked with UNODC, IOM, OHCHR, Chatham House, and the Nexus Institute, among others. She has delivered training to law enforcers and prosecutors; advised barristers, senators and legislators; and researched the challenges of implementing international law in national practice in Africa, Europe, Latin America, the Middle East and the South Caucasus. Marika has written book chapters and journal articles about migrant smuggling, human trafficking, migration and human rights, and their intersections, and has recently published a book titled Freedom from Religion and Human Rights Law (Routledge, 2017).Email: marika_mcadam@yahoo.com.au. 